\title{
The Application of Translation Method and Communicative Approach in German Education
}

\author{
Zhong Qingxuan \\ Jiangxi College Of Foreign Studies
}

\begin{abstract}
With the rapid development of our economic construction, modern society made higher requirements for quality and knowledge structure of foreign language professionals. Vocational colleges pay more attention to cultivating students, language knowledge ability and language application ability. As a result, foreign language teachers should not only help students to master foreign language knowledge but also note to cultivate the language communication skills of the students. This paper described, compared and analyzed the two representative teaching methods--traditional translation method and the current popular communicative approach. In combination with the current situation of the foreign language teaching method research at home and abroad, according to the training target and teaching characteristics of German major students in vocational college, it puts forward the comprehensive teaching method of traditional teaching combined with modern teaching.
\end{abstract}

Keywords-German education; German; Translation method; Communicative approach; Integral application

\section{INTRODUCTION}

With the increasing demand of minority language talents for vocational college, German language teaching in vocational college has been doing exploration and attempt. At present, the German majors opened in many vocational colleges are application German, with the teaching goal of strengthening foundation, familiar with skills, expanding scope of knowledge and cultivating practice ability. Pay attention to cultivating language application, professional ability, independent ability of students.

According to the talent cultivating goal and the talent cultivating task facing our German education, we find translation method combined with communicative approach is the effective teaching model suitable for German education. Translation method attaches great importance to grammar, which can deepen students' understanding of the target language but it neglects the language skills training thus can' t cultivate students' communication skills. While communication skills cultivate students' foreign language communication skills which is the target of mastering language training. But sometimes it' $s$ difficult to coordinate scientifically the relationship between communication skills and basic knowledge such as grammar. It has high requirements for teachers and hard to implement specifically.

As a result, this paper described, compared and analyzed the two representative teaching methods--traditional translation method and the current popular communicative approach. In combination with the current situation of the foreign language teaching method research at home and abroad, it proposes that in practical teaching process the traditional teaching method should be integrated with modern teaching.

\section{TRANSLATION METHOD AND COMMUNICATIVE} APPROACH

Translation method is a method teaching Greek and Latin in middle ages. It has different names due to different naming foothold in the development process. It $s$ named translation method according to the translation application in foreign language teaching and it' $s$ named grammar method or grammar translation method according to grammar as the language teaching basis .Although there are various translation methods, it has one origin. The most simple definition is as way to teach foreign languages in their native language. It' $s$ 
characteristic is in the process of foreign language teaching, native language and foreign language are often used together. Richards thinks that grammar method is a traditional foreign language and the second language teaching method, which takes translation and grammar learning as main teaching activities. Typical teaching is consisted of introducing grammar rule, learning vocabulary and translation exercises. It emphasizes reading rather that language communication ability.

Communicative approach, which is also called language teaching of communicative approach, is first called notional approach, functional approach or notional-functional approach. It" $\mathrm{s}$ basic concept is " notion", “function" and “ communication”. Communicative method is also called functional method or function- notional method. It' $\mathrm{s}$ a teaching system based on language function project, cultivating communication ability with language in specific social context.

\section{THE IMPLEMENTATION RESEARCH OF TRANSLATION} METHOD AND COMMUNICATIVE APPROACH TEACHING PRACTICE

\section{A. The application of translation method}

Foreign language study mainly refers to learning a foreign language in native language environment under the guidance of native language teacher, in a sense, translation method also reflects the essence of foreign language learning. Although translation method has been controversial over the years, it' $s$ still one of the effective means for teachers to teach language knowledge and students to learn foreign language. So, despite some disadvantages of the translation method, it has strengths which can' $t$ be replaced by other foreign language teaching methods. We should make best use of the advantages and bypass the disadvantages.

In teaching practice, we find translation method is still an effective method to help students learn a foreign language. However, with the development of the requirement of social and economic development and the deepening of foreign language innovation, our teaching method should also be improved and developed. Just for translation method, we should enhance the advantage, improve the shortage to better improve teaching quality of foreign language.

\section{B. The implementation of communicative approach}

We often encounter the problems during the process of German education: after several semesters' study of German, students have already learned the basic language structure and common vocabulary which are required by daily communication. But why many students can' $t$ use it skillfully? The answer is simple: Not enough practice causes poor language communication ability. As we see, we are not only learning language structure but the ability to use these language rules to communicate.

Currently, the basic skills of German majors in our country is OK but to be improved and poor language using competence. Language teacher should pay enough attention to this problem. They should find countermeasures in teaching according to students, actual situation. Not only the students master solid language foundation but to improve language using competence of the students and improve the comprehensive teaching quality.

\section{THE INTEGRATION OF TRANSLATION METHOD AND} COMMUNICATIVE APPROACH

1. Attach great importance to the German basic knowledge and basic skills (listening, speaking, writing and translating), cultivate the ability of students to use German to communicate. This principle reflects the main task of language teaching and the fundamental purpose of German teaching in vocational colleges. In the process of cultivating practical communicative ability, first we should make German as actual tool to teach and learn, do the communication as communicative approach advocated as much as possible and encourage the students to express themselves with German creatively.

2. Attach great importance to concise tutoring and more practice and mainly cultivate language actual communication skills. "Concise tutoring" refers to the teacher introduce appropriate theoretical knowledge and language rules. "More practice" refers to students should do a lot of practice in and after class and cultivate the proficiency of language use.

3. Attach great importance to creating German environment, increase German input and lay emphasis on 
the combination of self-study and natural acquisition. Language communication ability not only depends on classroom teaching, the language environment, contact scope of the learners as well as the input will directly affect German learning.

4. Attach great importance to language culture knowledge import. Language is the carrier of culture. Different language reflects different cultures. Communication barrier is a common problem in communication caused by different cultures. Therefore, teacher should teach culture knowledge in the process of teaching.

\section{CONCLUSION}

Grammar translation method and communicative approach are not two entirely opposite schools but are greatly complementary. Grammar translation method emphasizes the rational knowledge of language while communicative approach emphasizes the practical use of language but it doesn' $t$ exclude the application of grammar interpretation and translation method to some extent. Practice shows that translation method and communicative approach in German teaching are not only feasible but can achieve better teaching result. Students lay a solid foundation in language basic knowledge such as phonetics, vocabulary, grammar and rhetoric and have all-round development in basic skills such as listening, speaking, reading, writing and translating. In this way, they not only acquires basic language communication ability but cultivates the habit of think in German and self-study. However, there is no fixed mode as to how these two methods combine together. In specific teaching process, we must aim at the particularity of foreign language and the cultivation goal of foreign language talents in vocation college, adjust teaching methods according to different teaching contents and study stage. To sum up, either single use grammar translation method or communicative approach can enable students to master solid German language knowledge or communicate in German flexibly. Only the integration of these two methods can it really achieve the goal of using this language to listening, speaking, reading, writing and translating.

\section{REFERENCES}

[1] Hilgendorf, Suzanne K. "“ Brain Gain statt [instead of] Brain Drain ": the role of English in German education." World Englishes 24.1(2005):53-67.

[2] Educationalinnovation, Centre For. "From homogeneity to diversity in German education." Sourceoecd Social Issues/migration/health (2010).

[3] Wilde, Stephanie. "Secondary Education in Germany 1990-2000: 'one decade of non-reform in unified German education'?." Oxford Review of Education volume 28.1(2002):39-51.

[4] Auernheimer, Georg. "The German Education System: Dysfunctional for an Immigration Society." European Education 37.4(2005):75-89.

[5] Rosalind M. O Pritchard. "Was East German Education a Victim of West German 'Colonisation' after Unification?." Compare 32.1(2002):47-59.

[6] Merritt R L. Democratizing West German Education* [J]. Comparative Education, 1971, 7(3):121-136.

[7] Carstens, Carola, M. Rittberger, and V. Wissel. "Information search behaviour in the German Education Index." World Digital Libraries - An international journal 1(2011):69-80.

[8] Pritchard, Rosalind M. O. "British and German Education Students in a Shifting Scenario." Higher Education Management \& Policy 18.3(2006):1-23.

[9] Nicholls A J. The British Impact on German Education: a triumph for commonsense or missed opportunity ?[J]. Oxford Review of Education, 1978, 4(2):125-129.

[10] Brickman, William W. "Some Review Data on History of German Education." Comparative Education Review 8.3(1964):281-284.

[11] Lorenz, T. German education past and present /[M]// Charles Scribner's, 1912.

[12] Fuhr, Christoph. "The German Education System since 1945: Outlines and Problems." Adult Education (1996):335. 